\title{
Vývoj přípravy řidičů v českých zemích do roku 1989
}

\author{
Jan Štemberk
}

Fakulta humanitnich studii, Univerzita Karlova

Kontaktnie-mail: jan.stemberk@fhs.cuni.cz

The Development of the Driver Training in Czech Lands until 1989

\begin{abstract}
:
The paper sums up the requirements and demands for the driver training in Czech lands from the early 20th century to 1989 . This period is associated with several political changes that were reflected also in the training of drivers. In this context, the paper focuses on the driving schools and their legal status, the requirements for obtaining a driving license and the individual groups of these driving licenses. Since the obligation to undergo a driving test before driving had been implemented (1905), the content and difficulty of the driver training as well as other requirements (such as medical or professional) had been discussed. Particular attention is paid to the transformation of involvement of the state and the role it played in the trainings. The text of the article is largely based on the analysis of various regulations. To reveal the reality of the driver training and driving schools' activities, relevant archive sources and partly contemporary literature were used.
\end{abstract}

Keywords: drivers of motor vehicles; driving school; driver training; driving license

Klíčová slova: řidiči motorových vozidel; autoškola; výcvik řidičů; řidičský průkaz

DOI: $10.14712 / 2464689 X .2021 .6$

Financování: Text vznikl za finanční podpory Ministerstva kultury ČR v rámci projektu NAKI II České století motorismu (DG18P02OVV051), který v letech 2018-2022 realizují Univerzita Karlova Fakulta humanitních studií, Národní technické muzeum a Technické muzeum v Brně. 
V průběhu 20. století se automobil stal běžnou součástí života i českého právního řádu. Rozvoj motorismu a pohyb vozidel na veřejných silnicích vyvolal potřebu podrobit budoucího řidiče výcviku a zkoušce, které by skýtaly záruku bezpečného provozu. V české právněhistorické literatuře nebyla této problematice věnována dostatečná pozornost, ačkoli řada témat z minulosti je nadčasová. ${ }^{1}$ Dlouhodobě je řešena otázka kvalitní př́pravy řidičů a hledán kompromis náročnosti a dostupnosti výcviku. Novou není ani pozornost zaměřená na mladé řidiče jako rizikový faktor nehodovosti, či úvahy o vydávání řidičského oprávnění na omezenou dobu.

Cílem předložené studie je zmapovat vývoj výcviku řidičů od počátku 20. století do roku 1989 s důrazem na právní regulaci jejich přípravy. Požadavek na přípravu řidičů souvisel s rozvojem motorismu, nárůstem počtu vozů, schopností tyto bezpečně ovládat a častějšími dopravními nehodami, na kterých se motorová vozidla podílela. Právě v kvalitní přípravě řidičů byl postupně, a v zásadě do dnešních dnů je spatřován velmi důležitý faktor prevence nehodovosti. Studie se tak zaměřuje na průběh výcviku, oprávněné subjekty výcvik provádět i na řidičské zkoušky a nároky kladené na jednotlivé skupiny řidičských oprávnění. Text je založen nejen na rozboru právních předpisů, ale i na dobové literatuře a sondě do archivních pramenů, které více přibližují reálné dopady a průběh výcviku. Dílčím způsobem je použita i nepříliš rozsáhlá judikatura.

\section{Počátky před první světovou válkou}

Motorová vozidla do českého právního řádu poprvé vstoupila nařízením místodržitelství č. 13/1900 z. z. č. ze dne 27. ledna 1900. Po Dolních Rakousích, kde byl obdobný předpis přijat již o rok dříve, se jednalo o druhou zemi Předlitavska, která provoz motorových vozidel na veřejných cestách upravila. ${ }^{2}$ Otázce řidičů byla však věnována jen okrajová pozornost v $\$ 28$. Složení zkoušky nebylo povinné, ale je ho možné vnímat jako důrazně doporučené, jak z dikce tohoto ustanovení vyplývá: „Majetník automobilu nebo vozu motorového jest odpovědným za to, že vozidlo řídí jen takové osoby, jež jsou úplně k tomu způsobilými a ručí pak za každou škodu nebo nehodu způsobenou nezpůsobilostí, nepozorností nebo lehkomyslností řidiče, nesvěří-li řízení osobě, která svou způsobilost u místodržitelství prokázala a úřední vysvědčení o tom obdržela“. Příprava řidičů tak byla převážně v režii továren vyrábějících automobily. V počátcích automobilismu bylo řízení motorového vozidla, tedy zvláště jeho uvedení do provozu a praktické ovládání po technické stránce náročné a většinou si vyžadovalo školení, které tyto továrny byly schopné v provozu zajistit. Školení mělo převážně praktickou podobu, jak vůz ovládat a udržovat v chodu, jak dokládá i dobový zápis: „Na to byla s oběma předsevzata jízda na zkoušku v okrouhlé délce $10 \mathrm{~km}$ v trati, kteráž vykazuje náhlá stoupání a klesání. Oba shora jmenovaní střídavě řídili vưz pod dohledem montéra firmy, jenž vůz dodala, ... oba jmenovaní zručně dovedou stroj spouštěti a zastavovati a vưz vůbec spolehlivě říditi v různých rychlostech jízdy, a takže se navrhuje, aby oběma dáno bylo vysvědčení jako řidičům oprávněným automobilního nákladního vozu. Nakonec se připomíná, že svrchu označení po dobu dvou neděl byli

\footnotetext{
1 Z dílčích příspěvků např.: ŠTEMBERK, J. Právní regulace automobilismu v českých zemích do roku 1938. Právněhistorické studie, 2007, č. 38, s. 171-192.

2 Již z dřívější doby platila pravidla pro silniční parostroje, vyhláška místodržitelství č. 77/1875 z. z. č.
} 
v praxi při montování, jakož i při jízdě u firmy Daimler v Novém Městě u Vídně. “3 Důraz na znalost pravidel silničního provozu v této době velmi strohých byl spíše okrajový. ${ }^{4}$

Unifikaci pravidel provozu motorových vozidel na předlitavských silnicích přineslo nařízení ministerstva vnitra ve shodě s ministerstvem financí č. 156/1905 ř. z. z 27. září 1905. Nařízení v $\$ 21$ stanovilo pro řidiče minimální věk 18 let. Samostatně ř́dit motorová vozidla s výjimkou motocyklů bylo možné jen na základě úředního povolení (jízdné licence), dnes bychom řekli řidičského průkazu. Řidičský průkaz směl být udělen ,zpravidla toliko osobám, které prokázaly zkouškou svou způsobilost k řízení“ (§ 21 odst. 3). Řidiči „vozidel vojenskému eráru náležejících“ byli od složení zkoušky osvobozeni, „vykážou-li se o své způsobilosti vysvědčením technického komitétu vojenského“ (\$ 21 odst. 3). Z této použité formulace bylo vyvozováno, že výjimka platí jen pro vozidla patřící armádě a neplatila pro civilní vozidla vojenských osob, které by prípadně chtěly rídit. ${ }^{5}$ U zkoušky měla být ověřována teoretická znalost strojního zařízení motorových vozidel a současně též praktická způsobilost k řízení vozidla (§ 22 odst. 2). Vydaný řidičský průkaz měl být opatřen fotografií. Př́íprava řidičů na zkoušku byla jejich záležitostí a nebyla nijak upravena. Zkouška se skládala před komisařem jmenovaným místodržitelstvím (zemským politickým úřadem) a obvyklou praxí bylo, že si žadatel musel k praktické zkoušce opatřit automobil.

V souvislosti s uzavřením mezinárodní smlouvy o jízdě silniční v roce 1909 v Paříži, která přinášela změny v mezinárodní automobilové jízdě, musely být tyto mezinárodní závazky promítnuty i do vnitrostátního práva. Nově vydané nařízení ministerstva vnitra, které se stalo základem automobilového práva na následující čtvrtstoletí, bylo publikováno pod číslem č. 81/1910 ř. z. V § 22 přebíralo povinnost prokázat způsobilost k řízení motorových vozidel zkouškou. Novinkou byla možnost odepřít vydání řidičského průkazu osobě, která spáchala těžký přestupek proti životu a zdraví, trpěla tělesnými vadami, které by jí mohly v bezpečném řízení vozidla bránit, a také osobám s náklonností k nadměrnému požívání alkoholu. Následující § 23 zachovával výjimku pro řidiče vozidel vojenského eráru, pokud prokáží svou způsobilost k řízení. Způsobilost posuzovaly a průkaz způsobilosti (Befähigungszeugnis) vydávaly vojenské orgány. Zůstalo též zachováno, že tato výjimka se vztahovala jen k vojenským vozidlům, pro řízení civilních automobilů takový průkaz nemohl být využit. Novou kategorií se stala zdravotní způsobilost řidiče, která byla prokazována lékařským vysvědčením. Nutná byla bystrost zraku a schopnost sluchu. Dále se pozornost zaměřovala na zdraví srdce. Řidiči též měla být vlastní úplná abstinence či alespoň zdrženlivost v pití alkoholu. Od počátku nebyl činěn rozdíl mezi muži a ženami. Některé lékařské autority, např̀. prof. Heinrich Boruttan „povolání chaufferské ženám nedoporučuje, a to s ohledem na méně vzdorný ženský organismus“. ${ }^{6}$ Tyto argumenty sice zaznívaly, ale neprosadily se.

Zkoušky řidičů prováděli místodržitelstvím jmenovaní zkušební komisaři. Komisaři neměli určený přesný obvod své činnosti. Zkoušky řidičů prováděli nejprve dva zkušební

\footnotetext{
3 Národní archiv (dále jen NA), fond České místodržitelství, kar. 9806, sg. 55/8/3/47, Protokol z 22. 9. 1903.

$4 \quad$ K pravidlům silničního provozu srovnej: ŠTEMBERK, J. Automobilista v zajetí reality. Vývoj pravidel silničního provozu v českých zemich v první polovině 20. století. Praha: Karolinum 2008, s. 72 a násl.

5 Österreichisches Staatsarchiv, Allgemeines Verwaltungsarchiv (dále jen ÖStAAVA), fond Ministerium der Innern (dále jen MdI), k. 764, sg. 4g, Protokoll Nr. 35048/09.

6 TICHÝ, F. Hygiena automobilisty. Řidič automobilu, 1920, roč. 2, č. 22, s. 5.
} 
komisaři a tři náhradníci. Sídlem komisařů byla Praha a Liberec. V roce 1909 byl nově jmenován zkušební komisař v Plzni. Počet zkušebních komisařủ se zvyšoval jen velmi pomalu (od roku 1914 v Teplicích). Zkušební taxa činila pro řidiče automobilu $15 \mathrm{~K}$ a pro řidiče motocyklu s postranním vozíkem a tř́́kolky $10 \mathrm{~K}$. Uchazeč, který se na zkoušku sám připravoval, se s komisařem musel dohodnout na termínu zkoušky a sám si zajistit automobil, se kterým praktická část zkoušky proběhne. V rámci řidičských zkoušek byly uplatňovány čtyři skupiny - nákladní automobily, osobní automobily, motocykly s postranním vozíkem a tříkolky. Vůdčí list měl platnost ve všech zemích Předlitavska. Příprava na zkoušku závisela na uchazeči a mohl se na ni připravovat bud' sám, s využitím známého řidiče, nebo využít služeb nově vznikající živnosti autoškol.

Nařízení č. 81/1910 ř. z. stanovovalo jen rámcový průběh zkoušek. Podrobnosti vlastního průběhu byly na komisařích. Dolní Rakousy s Vídní se v roce 1912 vydaly cestou zpř́ísnění řidičských zkoušek. Podrobný průběh zkoušky proto obsahovaly vydané instrukce. U teoretické zkoušky musel uchazeč prokázat znalost pravidel provozu na silnicích, znalost základních součástí motorového vozidla, chování ve složitých situacích (např. požár vozu), pravidla kontroly bezpečnostních zařízení vozu před jízdou a rozpoznávání vad. Po úspěchu v teoretické části mohla následovat část praktická. Praktická část sestávala z kontroly funkčnosti brzd a řízení, uvedení motoru do chodu, rozjezdu vpřed a vzad, rychlého zastavení, zkušební jízdy na volné trati s různou náročností včetně potkávání se s jinými dopravními prostředky a poslední částí byla hodinová dálková jízda. ${ }^{7}$ Toto zpř́ísnění mělo do jisté míry reagovat na požadavek zkvalitnění prrípravy a zkoušek řidičů, avšak ve velké mírue mělo za následek to, že mnozí Vídeňané raději spěchali do Brna, kde byly kladené nároky nižší. ${ }^{8}$ Otázka zpř́ísnění ŕidičských zkoušek v době těsně před první světovou válkou byla aktuální a realizována nebyla jen v důsledku vypuknutí války.

Zavedení povinných zkoušek řidičů otevíralo prostor pro vznik autoškol, tedy institucí, které pomohou uchazeči s př́ipravou na zkoušku a jsou též schopny zajistit motorové vozidlo, které bylo pro vykonání zkoušky potřebné. Činnost autoškol nebyla nijak speciálně legislativně upravena, jednalo se o volnou činnost bez potřeby prokazovat svou způsobilost. Základní úpravu poskytovalo pouze císařské nařízení č. 309/1850 ř. z., prozatímní zákon o vyučování soukromém. Nařízení uvádělo, že ke zřízení soukromé školy je potřeba vznik školy tři měsíce před počátkem vyučování oznámit místodržitelství a pokud nepřišel zákaz, mohla být škola otevřena. Současně $§ 11$ zdůrazňoval, že vláda (stát) nijak neodpovídá za kvalitu poskytované výuky. Pravděpodobně první autoškola v Čechách vznikla v roce 1907 v Mladé Boleslavi, což nebylo s ohledem na místní automobilku Laurin \& Klement přkekvapující. ${ }^{9}$ Skutečnost, zda se někdo rozhodne soukromou školu navštěvovat, záviselo na každém jednotlivci. Již před první světovou válkou se vážně uvažovalo o potřebě zkvalitnit výuku v autoškolách a zařadit tyto školy mezi koncesované živnosti a posílit tím nad nimi dohled státu. V této době však výrazně převažovala individuální př́íprava, kdy se budoucí řidiči učili od svých zkušenějších kolegů. ${ }^{10}$

7 ÖStA AVA, fond MdI, kart. 761, sg. 14/2, Instruktion betrefend Prüfung der Führer von Kraftfahrzeuge, 1912.

8 Tamtéž, Chauffeurschullen, 23. 4. 1914.

9 Žáci bez učitele. Automobil, 1977, roč. 21, č. 8, s. 32-33.

10 ÖStA AVA, fond MdI, kart. 761, sg. 14/2, Chauffeurschullen, 23. 4. 1914. 


\section{Kontinuita př́ípravy řidičů ve 20. a první polovině 30. let}

Ministerské nařízení č. 81/1910 ř. z., ačkoli se o potřebě jeho novelizace jednalo již před první světovou válkou, zůstalo v platnosti i v novém Československu a $\mathrm{k}$ jeho nahrazení modernějším předpisem, který reagoval na růst motorismu, došlo až v polovině 30 . let. Precizovat pravidla zkoušek řidičů a přesněji stanovit jejich průběh mělo nařízení presidenta zemské správy politické v Praze z 22. dubna 1920 (č. 310/1920 Sb. z. a n.) o vyzkoušení motorových vozidel, jakož i zkouškách řidičů takových vozidel v Čechách (obdobný výnos byl vydán i pro Moravu a Slezsko). Zkoušky řidičů prováděli jmenovaní zkušební komisaři, kterým byl nově přidělen přesně vymezený obvod. Nařízení rozlišovalo stroje s motorem spalovacím, parním a elektrickým a v rámci těchto skupin vozy osobní a dodávkové, těžké nákladní vozy a motocykly s postranním vozíkem. Žádost o připuštění ke zkoušce byla podávána zemské politické správě, tedy v hlavním zemském městě, odkud byla postoupena místně př́slušnému zkušebnímu komisaři. Zkouška měla proběhnout do měsíce od podání žádosti. Uchazeč musel předložit potvrzení lékaře o zdravotní způsobilosti a doklad o své bezúhonnosti. Žadatel mohl uvést výslovně místo, kde si přeje zkoušku skládat, pokud toto místo nebylo sídlem zkušebního komisaře, musel platit jeho cestovné do zvoleného místa zkoušky. V př́padě neúspěchu mohl adept po uplynutí dvou měsíců požádat o reprobační termín. Zkušební taxa byla stanovena na 30 Kč, 3 Kč za kolek a poplatek za knížku (na počátku 20. let 3 Kč 20 hal.). Průběh zkoušky, její jednotlivé části a ani délka trvání nebyly upraveny a závisely na komisaři.

Prováděcí výnos české zemské správy politické z 22. dubna 1920 rozdělil Čechy na šest zkušebních obvodů (Praha, Liberec, Děčín, Teplice-Šanov, Plzeň a Cheb) a v každém obvodu jmenoval zkušebního komisaře. Obvykle se jednalo o stavebního radu, jen v Praze a Děčíně se jednalo o strojního komisaře. Největší byl obvod pražského zkušebního komisaře, který měl i svého zástupce. ${ }^{11}$ Oproti situaci před první světovou válkou se jednalo o zdvojnásobení počtu zkušebních komisařù.

Př́ípravě řidičů před složením zkoušky nebyla nadále věnována pozornost a příprava závisela na uchazeči. Žadatel měl pouze doložit, jak se na zkoušku připravoval. Nijak nebyla dotčena možnost individuální př́ípravy pod dohledem jiného řidiče. Výcvik mohl probíhat i v běžném provozu, třeba i při živnostensky provozované dopravě, tedy řidič a učedník se mohli při řízení v běžném provozu stř́dat. Výjimkou nebylo ani to, že si zájemce po koupi auta najal řidiče z povolání, pod jehož dohledem se připravil a následně se podrobil zkoušce a dále již ř́́dil sám. Úkolem adepta bylo i zajištění vozidla, na kterém byla zkouška prováděna. Za př́ípadnou nehodu nesl odpovědnost řidič, který výcvik zajišstoval.

Rozvoj automobilismu na jedné straně a snaha výrobců uvádět na trh vozidla hospodárnější, snazší na údržbu i obsluhu vedla ke zvyšování zájmu o řidičské průkazy. Růst motorizace se však negativně promítal do bezpečnosti na českých silnicích. Př́ičina růstu nehodovosti byla spatřována ve dvou jevech. Jedním bylo nesprávné chování chodců, kteří si stále ještě na automobily na silnicích plně nezvykli, a druhým bylo školení a zkoušení řidičů. Kritizována byla činnost soukromých autoškol slibujících po krátkém kursu (i dvou až tř̌i týdnů) složení zkoušky, činnost komisařŭ, kteří nevěnovali zkouškám náležitou pozornost a během několika minut proběhly jízdy i zkouška ze znalosti předpisů.

11 Technická hlídka. Jmenování členů zkušební komise. Řidič automobilu, 1920, roč. 2, č. 12, s. 3-4. 
Podle zjištění policejních orgánů se častěji na dopravních nehodách účastnili mladí řidiči, kteří neměli dostatek zkušeností. Často bylo poukazováno, že se ve složité dopravní situaci nesprávně zachovali, neodhadli chování jiného účastníka, př́padně př́liš hazardovali. Cesta $\mathrm{k}$ nápravě byla $\mathrm{v}$ tomto kontextu hledána ve zprŕísnění přípravy řidičů a zvláště zkoušek. „Žádné sebeostřejší policejní předpisy nemohou tak bezpečnost občanstva ochrániti, jako když řizení automobilu bude dáno jedině řádně vyzkoušeným a řádně vyučeným, spolehlivým řidičům." ${ }^{12}$

V tomto kontextu vznikl návrh senátorů Václava Klofáče a Ferdinanda Št’astného předložený v roce 1921. ${ }^{13}$ Návrh zvyšoval hranici pro možnost řídit motorové vozidlo na 19 let. Ke zkoušce měli být připuštěni pouze uchazeči, „kteří, jsouce prakticky vyučeni některému z kovoobráběcích odborů“. Tento návrh samozřejmě nemohl mít naději na úspěch. Minimální věk řidiče 18 let vycházel z mezinárodních závazků (pařížské úmluvy o jízdě motorovými vozidly z roku 1909) a také požadavek, aby všichni řidiči byli absolventy kovoobráběcích oborů, byl zcela nereálný. Dolehl by zvláště na př́ležitostné řidiče amatéry. Proti tomuto návrhu se samozřejmě postavil Československý klub automobilistů, ale odpůrci byli i mezi zákonodárci. Ani uplatnění těchto požadavků u řidičů z povolání nemělo naději na úspěch, nebot' úřady v této době odmítaly provádět mezi řidiči takové dělení. Skutečnost, zda bude někdo dobrým řidičem, nezávisela na tom, je-li zkušeným automontérem a umí opravit každou závadu, ale na chladnokrevnosti, pohotovosti a bystrosti.

Ruku v ruce s tímto návrhem šla myšlenka postátnění přípravy řidičů. Soukromé autoškoly, kterým byla vytýkána nesvědomitost při př́ípravě řidičů, měly být zrušeny. Řidičské kursy měly být nadále organizovány pouze při státních průmyslových školách. Tyto školy měly garantovat kvalitu kursu a dohlédnout na jeho průběh. Př́íprava řidičů měla být náročná a následná zkouška př́sná. ${ }^{14}$ Převzetí prrípravy řidičů státem by si vyžádalo vysoké investice na nákup vybavení a cvičných vozidel. Většina se tak klonila k ponechání př́pravy řidičů na soukromých autoškolách, ale zvýšení dohledu nad nimi a zajištění výuky zkušenými učiteli. Nicméně je potřebné poukázat, že otázka autoškol nebyla zvláště aktuální, nebot' jejich služeb využívalo jen cca 15 \% uchazečů. Většina se na zkoušku nadále připravovala individuálně. ${ }^{15}$

Ze zachovaných dobových inzerátů můžeme získat rámcový přehled o ceně a délce řidičských kursů. První automobilová škola ing. Kováŕík-Vinohrady nabízela kurs v trvání 6-8 týdnů, za jehož absolvování adept zaplatil 900 Kč. Levněji vyšla příprava v První odborné koncesované automobilní škole ing. Brožík a Jakoubek, a sice na 760 Kč. Absolvování řidičského kursu se mohlo stát i součástí lázeňského pobytu. Př́ikladem jsou lázně Luhačovice, kde v roce 1928 otevřeli autoškolu, která ,dávala možnost vyučit se v krátké době řízení auta pánům i dámám“. 16

12 Zamezte soukromé a pokoutné vyučování v řízení automobilu. Řidič automobilu, 1922, roč. 4, č. 11, s. 3.

13 Národní shromáždění RČS 1920-1925, Senátní tisk č. 736. [online]. Dostupný na: https://www.psp.cz/ eknih/1920ns/se/tisky/t0736_00.htm. [cit. 31. 12. 2020].

14 Návrh senátorů V. Klofáče, F. Št’astného a spol. na vydání zákona o státních cvičebních kursech pro řidiče automobilů. Řidič automobilu, 1921, roč. 3, č. 19, s. 3.

15 ŠKOULA, J. Může býti každý dobrým řidičem automobilů? Lidové noviny, 6. 2. 1927, s. 21.

16 Do lázní Luhačovic. Národní listy, 14. 4. 1928, s. 7. 


\section{Modernizace výcviku řidičů ve druhé polovině 30. let}

I přes bohatou diskusi byly změny přípravy řidičů řešeny až v souvislosti s rekodifikací „automobilového“ práva v roce 1935. Základní pravidla stanovil zákon č. 81/1935 Sb. z. a n. o jízdě motorovými vozidly, který výcviku řidičů věnoval oddíl XII. Konečně též byla sjednocena pravidla platná v českých zemích se situací na Slovensku a Podkarpatské Rusi. Samozřejmostí bylo vázání ř́zení motorového vozidla na získání řidičského průkazu, které měl nově mít každý řidič, tedy i řidič motocyklu. ${ }^{17}$ Řidičské oprávnění mohl získat po složení zkoušky každý československý občan, který dosáhl věku 18 let ${ }^{18}$ a byl lékařem ustanoveným okresním úřadem uznán za tělesně a duševně způsobilého. Zákon ve své podstatě zaváděl zvláštní kategorii řidiče z povolání (§ 12 odst. 4), ale pouze ve vztahu $\mathrm{k}$ ř́zení motorových vozidel určených k veřejné dopravě osob. Pro takového řidiče byl vyžadován věk alespoň 24 let, trríletá řidičská praxe a splnění přísnějších požadavků na tělesnou a duševní způsobilost, včetně psychotechnického vyšetření a dvouleté periody lékařských prohlídek. Podrobnosti o průběhu a obsahu řidičské zkoušky a o specifických nárocích na řidiče veřejných dopravních prostředků upravovalo dále prováděcí vládní nařízení č. 203/1935 Sb. z. a n.

Vyučovat řízení motorových vozidel mohla jen osoba, která k tomu získala povolení (§ 72 zákona). Povolení mohlo být zemským úřadem, případně úřadem školské správy, pokud se jednalo o učitele veřejných škol podřizených ministerstvu školství a národní osvěty, uděleno ,učitelským osobám na veřejných školách zabývajících se výcvikem řidičů, jakož i majitelům a zaměstnancům soukromých po živnostensku provozovaných podniků pro výcvik řidičư‘, dále též majitelům podniků vyrábějících či prodávajících motorová vozidla a ,podniků používajících většího počtu motorových vozidel“, jakož i zaměstnancům těchto podniků a zaměstnancům těch úřadů nebo hasičských sborů, které používaly většího počtu motorových vozidel, za podmínky, že dosáhli věku 25 let a nejméně tři roky byli držiteli řidičského oprávnění, které skutečně vykonávali, za předpokladu, že poskytují záruku svědomitého a důkladného vyučování. Oprávnění těchto osob se vztahovalo jen na výcvik žáků školy, zaměstnanců podniku či osob kupujících si motorové vozidlo. Bez povolení ( $\$ 72$ odst. 5) mohl nového řidiče ve výjimečných a ojedinělých př́ípadech připravovat řidič, který měl praxi v řízení motorových vozidel po dobu tří let. Muselo se tak dít bezúplatně a bylo počítáno, že tato možnost se uplatní spíše u rodinných příslušníků či známých.

Nejasná formulace $\S 72$ odst. 5 zákona č. 81/1935 Sb. z. a n., tedy oprávnění každého řidiče $\mathrm{s}$ tříletou praxí $\mathrm{k}$ př́íležitostnému nevýdělečnému výcviku, činila v praxi potíže. Jasná pravidla výkladu poskytlo až rozhodnutí Nejvyššího správního soudu ze dne 19. června 1941 (SJS 156/40), které stanovilo, že oprávnění osoby provádět výcvik bez povolení se vztahuje jen na jízdy, jejichž účelem je naučit adepta ovládání vozu. Adept tak nemohl řídit vozidlo při jakékoli jízdě, ale jen při učební jízdě, ze které muselo být zřejmé, že její jediný cíl je výcvik řidiče. Pokud bylo známo, že adept již řízení vozu ovládá, nemohlo se jednat o učební jízdu.

17 Vládním nařízením č. 264/1937 Sb. z. a n. byli řidiči motocyklů bez bočního vozíku (sidecar) opět vyňati z povinnosti složit řidičskou zkoušku.

18 Rídit jízdní kola s pomocným motorkem a traktory mohly osoby již od 16 let ( 5 odst. 1 zákona č. 81/1935 Sb. z. a n.). 
Pozornost byla věnována i autoškolám. Provozování autoškoly bylo prohlášeno za koncesovanou živnost (§ 73). Předpokladem udělení koncese bylo získání povolení k výcviku řidičů. Autoškolu mohla provozovat jen osoba k výcviku řidičů oprávněná a mající odbornou a praktickou způsobilost. Odborná způsobilost se prokazovala vysokoškolským vzděláním v oblasti strojní či elektrotechnické a praktická způsobilost alespoň tř́letou praxí při výrobě, opravách nebo provozu motorových vozidel. K žádosti o koncesi bylo nutné předložit učební osnovy a délku plánovaných kursů. Koncesi uděloval zemský úřad podle sídla autoškoly.

Teoretická příprava v autoškole spočívala ve školení adeptů ve znalosti pravidel silničního provozu, v obeznámení s poskytováním laické první pomoci, poučení o konstrukci motorových vozidel a dále v důkladném osvětlení funkce, údržby a odstraňování poruch těch zařízení vozidla, která mají význam pro bezpečnost (brzdy, řízení apod.). Kurs nesměl být kratší než tři týdny a při praktických jízdách v provozu musel každý adept ujet alespoň $120 \mathrm{~km}$. Dále měl být obeznámen, jak se chovat ve výjimečných situacích (např. smyk), a též s výměnou pneumatik ( $\$ 132$ a násl. vl. nař. 203/1935 Sb. z. a n.).

Zkouška probíhala před zkušebním komisařem jmenovaným zemským úřadem. Maximální poplatek za zkoušku zůstával na částce 30 Kč. Díky takto celkem nízko stanovenému poplatku bylo získání řidičského průkazu dostupné širokým vrstvám obyvatelstva. Žádost o složení zkoušky se nově podávala okresnímu úřadu podle místa bydliště. Termín zkoušky měl být stanoven do šesti týdnů od podání žádosti. Zkouška měla ústní a praktickou část. Součástí ústní části bylo osvědčení znalosti právních předpisů provozu motorových vozidel, znalosti součástí a mechanismů motorového vozidla a všeobecných znalostí o poskytování první pomoci. Praktická zkouška měla prokázat bezpečné ovládání motorového vozidla. Přistavení vozidla pro praktickou část zkoušky musel nadále zajišt'ovat uchazeč. Zrušen byl rozdíl mezi řízením civilních a vojenských motorových vozidel. Osvědčení o způsobilosti k řízení vozidla vydané vojenskou zprávou nahrazovalo odbornou způsobilost řidiče ( $\$ 78$ vl. nař. 203/1935 Sb. z. a n.).

Vládní nařízení č. 203/1935 Sb. z. a n. (\$ 68) rozeznávalo čtyři kategorie řidičských oprávnění. Řidičský průkaz I. kategorie opravňoval k řízení dvoukolových motorových vozidel, II. kategorie umožňoval řídit motorová vozidla více než dvoukolová do celkové hmotnosti 2,6 tuny. Motorová vozidla o hmotnosti od 2,6 do 3,5 tuny opravňoval řídit řidičský průkaz III. kategorie. Poslední IV. kategorie zahrnovala motorová vozidla o celkové hmotnosti nad 3,5 tuny bez ohledu, zda sloužila k dopravě osob či nákladů. V rámci těchto kategorií byly ještě rozděleny tři skupiny podle typu pohonu (spalovací, parní, elektrický). Řidičský průkaz vyšší kategorie opravňoval i k řízení vozidel spadajících do nižší kategorie.

\section{Harmonizace výcviku řidičů v ř́ísi a protektorátu}

Okupace českých zemí v březnu 1939 ovlivnila i pravidla silničního provozu a řidiče, a to nejen obecně známým urychleným přechodem na pravostranný provoz. Oblast pravidel silničního provozu měla být podle přání okupantů harmonizována se situací v ř́šsi, tak jako $\mathrm{k}$ tomu došlo po anexi českého pohraničí. ${ }^{19}$ Základním předpisem, který pravidla řízení motorových vozidel upravoval, bylo vládní nařízení č. 243/1939 Sb. z. a n. o připuštění

19 Podrobněji srovnej: ŠTEMBERK, Automobilista v zajetí reality, s. 118 a násl. 
osob a vozidel k dopravě na silnicích. Řízení motorových vozidel včetně motocyklů bylo vázáno na řidičský průkaz. V souladu s přechodnými ustanoveními ( 72 odst. 6) bylo řízení motocyklů bez řidičského průkazu možné až do 1. července 1940. Řidičská oprávnění zůstávala rozdělena do čtyř tříd, které však byly ve srovnání s dosavadním stavem zcela odlišné (§5). První třída opravňovala k řízení motocyklů s obsahem válců přes $250 \mathrm{ccm}$. Druhá tř́́da umožňovala řídit motorová vozidla s vlastní hmotností převyšující 3,5 tuny. Třetí třída, která byla v podstatě nejrozšsiřrenější, byla vymezena negativně, tedy opravňovala k řízení vozidel nespadajících do žádné z ostatních kategorií. Držitel řidičského průkazu čtvrté trrídy mohl řídit motorová vozidla do obsahu válců $250 \mathrm{ccm}$, tedy menší motocykly, a vozidla schopná dosáhnout rychlost max. $20 \mathrm{~km} / \mathrm{h}$ (např. traktory). Skupiny podle druhu pohonu zůstaly zachovány. Řídit vozidla spadající do čtvrté kategorie mohly osoby starší 16 let, u ostatních motorových vozidel byl vyžadován věk 18 let. Zavedené třídy řidičských oprávnění byly identické se stavem platným v Německu.

Uchazeč o řidičskou zkoušku se již nemusel obligatorně podrobit lékařskému vyšetření způsobilosti, to přicházelo v úvahu pouze, pokud zkušební komisař při zkoušce pojal podezření, že uchazeč není zdravotně způsobilý. Pro získání řidičského průkazu čtvrté kategorie nebylo složení zkoušky podmínkou, ze základní znalosti předpisů byl oprávněn žadatele přezkoušet přímo úřad vydávající řidičský průkaz. Pro průkazy ostatních tříd již bylo složení zkoušky před zkušebním komisařem nezbytné. Předmětem zkoušky nově nebyly znalosti z poskytování první pomoci. Povolení k řízení mohly dále vydávat svým zaměstnancům bezpečnostní orgány a protektorátní pošta a dráhy. Tato povolení platila i pro soukromá vozidla a mohla být vyměněna za běžný řidičský průkaz odpovídající kategorie (\$14). Změny se dotkly i př́pravy řidičů. Adepta mohl na zkoušku připravovat jen řidič, držitel řidičského průkazu prŕíslušné kategorie, který byl držitelem oprávnění k výcviku řidičů motorových vozidel (§ 3 vl. nař. 241/1939 Sb. z. a n.). Tímto ustanovením tak byla zrušena možnost individuální přípravy a v zásadě se zaváděla obligatorní příprava řidičů s oprávněným učitelem jízdy.

Před zapsáním do kursu pro řidiče musel uchazeč získat povolení, že kursy může navštěvovat. Bez povolení bylo možno získat jen řidičský průkaz čtvrté třídy, pro jehož získání nebyla návštěva kursů potřebná. K udělení povolení (Dringlichkeitsbescheinigung) byly oprávněny orgány okupační správy oberlandraty. Povolení mohlo být uděleno jen ve zvláště důležitých př́ípadech, napřr. při zajištění provozu vozidla, jemuž bylo uděleno povolení k jízdě. ${ }^{20}$ To samozřejmě vedlo k poklesu zájmu o řidičské průkazy a k zastavování činnosti autoškol, které neměly žáky nezbytné pro svůj provoz. Jen v roce 1940 jich ukončilo svou činnost 44. Uplatňování rasových předpisů se projevilo i u řidičů motorových vozidel. Výnosem ministerstva vnitra z 11. ledna 1941 bylo nařízeno, aby neárijci odevzdali do 14 dnů své řidičské průkazy. Výjimku z tohoto obecného nařízení představovaly jen důležité hospodářské zájmy. Současně bylo zakázáno přijímat neárijce do autoškol. Tento krok byl odůvodňován nižšími schopnostmi neárijců a obavou z páchání devizových a hospodářských deliktů. ${ }^{21}$

\footnotetext{
20 NA, fond Ministerstvo vnitra (dále jen MV), kart. 6931, č. 13/18/30, Spis č. 23592 z 22. 9. 1941; Postup k získání řidičského průkazu pro motorové vozidlo. Auto, 1942, roč. 24, s. 131.

21 NA, fond MV, kart. 6931, č. 13/18/8, Zpráva policejního ředitelství v Praze z 27. 2. 1941, č. j. 55836.
} 
Zavedení odlišných kategorií řidičských průkazů a také postupující germanizace zasahující veškeré veřejné listiny vedly k vydání vládního nařízení č. 179/1941 Sb. z. a n. o výměně řidičských průkazů pro motorová vozidla. Nové průkazy byly dvojjazyčné. Řidičské průkazy vydané před 1. listopadem 1939 ztrácely platnost k 15. květnu 1942. Vládní nařízení obsahovalo pravidla pro výměnu a vzájemný poměr starých kategorií a nových tříd řidičského oprávnění. Zkoušky řidičovy odborné způsobilosti se při výměně neprováděly.

V pohraničních oblastech odstoupených na podzim 1938 Německu byla na základě nařízení říšského ministra dopravy z 16. září 1939 provedena výměna dosavadních československých řidičských průkazů za německé, obdobně jako o dva roky později v protektorátu. Navazovalo to na zavedení ŕíšských pravidel silničního provozu. V otázce př́pravy řidičů zůstávala v platnosti oprávnění, která získali učitelé jízdy podle československých předpisů. Dosavadní autoškoly mohly pokračovat v činnosti, a naopak nebylo povoleno pronikání autoškol z vlastního Německa (staré říše). ${ }^{22}$ Postupně se v přípravě řidičů posilovala úloha Nacionálně socialistického motoristického sboru (Nationalsozialistisches Kraftfahrkorps /NSKK/), který byl od 1. února 1939 jako jednotná celostátní organizace motoristů pověřen výchovou řidičů. ${ }^{23}$ Od 1 . ledna 1944 byla tato organizace prŕpravou řidičů pověřena bezvýjimečně. Žadatel o řidičský průkaz musel předložit Dringlichkeitsbescheinigung, tedy souhlas správních úřadů s řidičským výcvikem, bez tohoto souhlasu nemohl výcvik proběhnout. Poplatky za řidičské kursy byly stanoveny paušálně (1. třída 15 ř́šských marek/RM/, 2. třída $25 \mathrm{RM}+8 \mathrm{RM}$ za hodinu jízdy, 3. tř́da $25 \mathrm{RM}+5 \mathrm{RM}$ za hodinu jízdy). ${ }^{24}$ Řidičské průkazy čtvrté třídy jako tzv. Kriegskraftfahrschein byly vydávány př́mo Motorstandartami NSKK. ${ }^{25}$ Mimo možnost výcviku a řízení motorových vozidel stálo židovské obyvatelstvo. Pokračující válka paradoxně zlepšila v tomto směru postavení Čechů, kteří v pohraničí zůstali. S narůstajícím nedostatkem řidičů mohli být zařazeni do výcviku za podmínky, že ovládali německý jazyk. ${ }^{26}$

V otázkách fungování autoškol, jejich instruktorů a průběhu řidičských kursů zůstávaly na počátku protektorátu zatím v platnosti dosavadní předpisy. Novou úpravu přineslo až vládní nařízení č. 415/1941 Sb. z. a n. o výcviku řidičů automobilů. Vzdělávání řidičů bylo na podnět úřadu ř́šského protektora upraveno v souladu s německým právem. Byla zavedena nová instituce učitelů jízdy z povolání. Výcvik řidičů mohl provádět zkušený řidič skýtající záruku řádné př́ípravy, který dosáhl věku alespoň 25 let a získal k tomu povolení od zemského úruadu. Výcvik mohl provádět jen v těch řidičských kategoriích, jejichž byl držitelem. Činnost autoškol (soukromých škol pro výcvik řidičů motorových vozidel) zůstávala nadále koncesovanou živností. Podrobněji byla upravena jen teoretická výuka,

22 Státní okresní archiv (dále jen SOkA) Chomutov, fond Landrat Chomutov, kart. 48, sg. PolIVf2, Tschechische Führerscheine, 15. 7. 1941; Tamtéž, sg. PolIVf4, Fahrlehrer, 5. 6. 1939.

23 ŠRAML, J. E. Výcvik mladých motoristů v Německu. BSČM, 1939, roč. 2, č. 4, s. 2

24 SOkA Chomutov, fond Archiv města Klášterec nad Ohří, k. 88, sg. 121/20, Wie erhalte ich den Führerschein, 12. 2. 1944

25 Archiv města Ostravy, fond Národněsocialistický Svaz motoristů, motorstandarta 214 Moravská Ostrava, i. č. 1, Führerscheine, 29. 12. 1943.

26 SOkA Chomutov, fond Landrat Chomutov, kart. 48, sg. PolIVf2, Erteilung von Führerscheine an Tschechen, 30. 8. 1943 . 
jejíž obsah se neměnil. Vytratila se ustanovení o minimální délce kursů i o minimálním počtu ujetých kilometrů (§ 13).

Nedostatek pohonných látek a hledání jejich náhražek zasáhlo i př́ípravu řidičů. Rozšiřování pohonu prostřednictvím generátorového plynu (dřevoplynu) vyvolalo přijetí vládního nařízení č. 84/1942 Sb. z. a n. o řízení motorových vozidel hnaných generátorovým plynem. K řízení a obsluze takto vybaveného vozidla bylo potřebné zvláštní povolení, které vydával okresní úřad, pokud žadatel vhodným způsobem prokázal, že je dostatečně obeznámen s obsluhou a řízením takto vybaveného vozidla. Obsah byl tedy ryze technický. Ve své podstatě se jednalo o doplnění nové skupiny řidičských oprávnění.

\section{Poválečné hledání modelu výcviku řidičů}

Doba válečná a poválečná vedla k omezování motorismu a používána mohla být jen vozidla, která měla k provozu povolení. To samozřejmě ovlivňovalo i možnost přípravy řidičů. Oproti původním dohodám se Slovenskou národní radou z července 1945, na kterých bylo ujednáno, že na celém území státu bude proveden návrat $\mathrm{k}$ úpravě pravidel provozu na silnicích, a tedy i př́pravě řidičů provedené zákonem č. 81/1935 Sb. z. a n., začalo nedlouho poté ministerstvo dopravy trvat na platnosti (použivatelnosti) všech protektorátních předpisů, které automobilismus upravovaly. Poukazovalo hlavně na jejich přínos $\mathrm{k}$ bezpečnosti silničního provozu. ${ }^{27}$ Tento postup však vedl k rozdvojení právní úpravy v českých zemích a na Slovensku, kde zůstávaly po celou dobu okupace v tomto odvětví v platnosti meziválečné československé předpisy. Komplikací, které byly spojeny s rozdílným právem v českých zemích (patrný byl i odpor českých motoristů proti protektorátním nařízením) a na Slovensku, si bylo vědomo i ministerstvo dopravy. Vyvstávala tu i nejistota bezpečnostních orgánů, podle kterých norem mají při kontrolách postupovat. Nejasnosti panující v dokumentech, které byly nutné pro jízdu, byly překonávány záplavou směrnic pokoušejících se jednotlivé sporné otázky vyjasňovat. ${ }^{28} \mathrm{~S}$ ohledem na přípravu mezinárodní konference byla unifikace odkládána až do roku 1950.

Př́prava řidičů a průběh zkoušek nedoznávaly po osvobození podstatných změn a dosavadní pravidla zůstávala nadále $\mathrm{v}$ platnosti. V době ohrožení státu, jak před válkou, tak i v době poválečné, se stávala aktuální otázka brannosti v motorismu. Jedním z požadavků bylo vycvičit velký počet řidičů připravených nasadit své síly k obraně vlasti. V době předválečné byl v roce 1938 uveden v život Branný svaz československých motoristů, který se na proškolení širokých vrstev zaměřil, bohužel však s ohledem na krátkost své existence nemohl dosáhnout podstatnějších úspěchů. Za úspěch je možné označit vyškolení více než 10 tisíc řidičů v průběhu roku $1938 .{ }^{29}$ Po roce 1945 byla idea vybudovat branně výchovné motoristické školství obnovena. Zaměření již mělo být výlučně na mládež obou pohlaví, aby po 18. roce mohla složit zkoušky a nezatěžovala vojenský výcvik. Na tomto základním

27 NA, fond Ministerstvo vnitra-nová registratura, kart. 425, sg. A 2535/24, Zprávy Ministerstva dopravy z 27. 6. 1945 č. B2123-8/6-45; ze 4. 9.1945 č. D-9738/45-VII/4.

28 Např. byly uznávány nejen vyměněné protektorátní řidičské průkazy (podle nařízení z roku 1941), ale i staré meziválečné průkazy, které vyměněny nebyly. NA, fond Zemský úřad Praha - Zemský národní výbor referát dopravní průmyslový, pro pozemkovou reformu, vnitřní osídlení a komise pro zjištění válečných škod, kart. 125, č. 15/1946, Směrnice Ředitelství národní bezpečnosti č. 93.386/45.

29 Podrobněji srovnej. ŠTEMBERK, J. Branný sbor československých motoristů 1938-1939. Moderní dějiny, 2020 , roč. 28 , č. 2 , s. 217-242. 
výcviku se měla podílet armáda. ${ }^{30}$ To, že se ve větší míře jednalo jen o plány, které nebyly realizovány, asi není nutné zdůrazňovat. Současně se však ukazovalo, že plány tohoto zaměření vedly spíše k poskytování nejrůznějších úlev uchazečům a tím byla náročnost výcviku snižována.

Dekretem ministerstva školství, vědy a umění ze dne 30. záŕí 1948 byla zavedena kumulativní národní správa do soukromých učilišt', což se týkalo i autoškol. Usnesením kumulativní národní správy ze 7. prosince 1948 bylo rozhodnuto, že výcvik řidičů motorových vozidel může být nadále prováděn pouze v jejím rámci. Krok byl odůvodněn potřebou zajištění jednotné př́pravy. ${ }^{31} \mathrm{~V}$ pojetí státních orgánů prestiž autoškol stále vzrůstala, ale kontury budoucího stavu byly probírány v průběhu celého roku $1949 \mathrm{~s} \mathrm{tím,}$ že vývoj jednoznačně směřoval k centralizaci prŕípravy budoucích řidičů. Autoškoly měly zajistit jejich kvalitní př́ípravu. Výkonem národní správy nad autoškolami byla pověřena organizace motoristů - Autoklub Republiky Československé. Dosavadní autoškoly mohly nadále výcvik se svolením ministerstva školství, věd a umění a za jím stanovených podmínek poskytovat. Byl to projev představy určité motoristické samosprávy, kdy by př́prava motoristů byla plně v rukou organizace motoristů, a tedy motoristů samotných.

Vedle přípravy řidičů nových se otevíralo i nové téma doškolování a přezkušování řidičů stávajících, pro které se též motoristická organizace jevila vhodnější. Tedy ti nejlepší motoristé budou předávat své zkušenosti kolegům. Ve druhé polovině 40. let byla postupně uvolňována omezení pro provoz motorových vozidel zavedená v době okupace. $\mathrm{Na}$ silnice tak mohli vyjet řidiči, kteří za volantem řadu let neseděli, ztratili patřičné návyky a zapomněli ustanovení pravidel silničního provozu, či si nová z roku 1939 neosvojili. Tomuto riziku chtělo ministerstvo dopravy čelit povinným doškolením a přezkoušením všech řidičů, kteří získali řidičský průkaz před 1. říjnem 1948, a pokud neuspěli ani při opravné zkoušce, měl jim být řidičský průkaz odebrán. ${ }^{32}$ Doškolení mělo formu tř́ dvouhodinových lekcí zaměřených na pravidla silničního provozu, poté následovala zkouška. ${ }^{33}$ $\mathrm{S}$ ohledem na počty uchazečů o přeškolení bylo nutné hledat vhodné prostory, nejvíce se osvědčily závody, v nichž řidiči pracovali, kde byla dostatečná kapacita prostor. Naopak se jako zcela nevyhovující ukázaly sály v hostincích, kde účastníci během přednášek i přes výstrahy popíjeli alkoholické nápoje. ${ }^{34}$

\section{Výcvik řidičů v rámci organizace motoristů}

Po válce připravovaná nová pravidla silničního provozu byla vydána v zákoně č. 56/1950 Sb. Zákon samozřejmě obsahoval i část věnovanou výcviku řidičů. Řízení motorových vozidel bylo nadále vázáno na řidičský průkaz, který mohla získat jen osoba, která prokázala svou odbornou způsobilost (§ 12). Výcvik řidičů byla oprávněna provádět ,jednotná celostátní organisace československých motoristů ve zvláštních učilištích“ (§ 11). Ve své podstatě se nejednalo o nijak revoluční myšlenku, byla sice spojena se státy typu nacistického Německa či Sovětského svazu, ale svou výcvikovou sekci měl od března 1939

\footnotetext{
30 Školy národného motorizmu. Automoto, 1946, roč. 1, č. 2-3, s. 45.

31 NA, fond Úrad předsednictva vlády (dále jen ÚPV), kart. 61, i. č. 816, sg. 153/40.

32 NA, fond ÚPV, kart. 61, i. č. 805, sg. 153/7, Spis č. 102071/49 z 22. 4. 1949.

33 Slovenský národný archív (dále jen SNA), fond Povereníctvo vnútra - bezpečnostný odbor (dále jen PV-BO), kart. 472, sg. BC, Spis 230/231-BC-49.

34 Tamtéž, kart. 472, sg. BC, Spis 258/33-BC-49
} 
i Autoklub Republiky Československé. ${ }^{35}$ Výcvikem mohly být pověřeny i jiné právnické osoby, pokud to vyžadoval zájem výcviku. Dále bylo provádění výcviku svých žáků v řízení dáno školám „směru automobilního, dopravního a strojnického“. „Výcvik zemědělských traktoristů mohou provádět též Ústředí pro mechanisaci zemědělství, národní podnik, a zemědělské školy pro své žáky“ (§ 11). Veškerý výcvik měl být prováděn podle jednotných zásad a vyučovat mohla jen osoba, která k tomu získala povolení od krajského národního výboru. Instituce povolení pro učitele jízdy byla ponechána, nebot' se podle dobových představ osvědčila. Učitel jízdy však mohl být činný jen v rámci povoleného učiliště a nikoli samostatně. ${ }^{36}$

Zákon dovršil též zánik soukromých autoškol (§ 22), když zrušil všechny koncese opravňující autoškoly provozovat. Argumentem proti soukromým autoškolám byl jejich zájem o podnikatelský zisk, který měly upřednostňovat před kvalitní př́pravou řidičů. Soukromé školy tím neposkytovaly záruku řádného a důkladného výcviku. Výcvik a výchova řidičů tak měly být svěřeny samotným motoristům (jednotnému autoklubu), čímž měla být dána ,záruka odborného, svědomitého, levného a nejširším masám pracujícího lidu přístupného výcviku“a „tím budou dány též předpoklady pro zlidovění motorismu“. 37

Bližší pravidla stanovovalo prováděcí nařízení vlády č. 11/1951 Sb., které však i tak zůstávalo velmi obecné. Výchovu řidičů přejímal stát (§ 63). Nároky kladené na budoucí řidiče se neměnily. Také z pohledu věku řidičů nedošlo k zásadním změnám, jen pro řidiče autobusů byl obecně stanoven minimální věk 21 let. Podrobnosti a průběh zkoušky stanovoval zkušební řád. Dohled nad průběhem zkoušek byl svěřen krajským národním výborům. Ministerstvo dopravy ve shodě s ministerstvem národní bezpečnosti mohlo prováděním zkoušek pověřit i učiliště provádějící výcvik řidičů (§ 58). Novinkou se stávala možnost zavedení vložky (kuponu) do řidičského průkazu ${ }^{38}$ (§ 59), kde mohly být zaznamenávány nejvážnější dopravní přestupky a bylo tedy možné sledovat př́ípadnou recidivu. Nová byla též možnost omezit dobu platnosti řidičského oprávnění a stanovení podmínek pro jeho obnovení ( $\$ 62$ ). Jen v rovině úvah zůstávalo zavedení řidičského průkazu u začínajících řidičů na zkoušku, kdy by po určité době museli být opět přezkoušeni. Pro řidiče vozidel užívaných v silničním dopravním podnikání nebo autobusů byl stanoven minimální věk 21 let, trríletá praxe v řízení motorových vozidel a platily přísnější podmínky tělesné a duševní způsobilosti (§ 61). ${ }^{39}$

Na základě uvedeného zákona byla vydána vyhláška č. 407/1950 Ú. 1. s organizačním řádem učilišst' pro výcvik řidičů, v návaznosti na něj stanovila přesnou učební osnovu i minimální hodinovou dotaci v rámci přípravy na jednotlivé skupiny řidičských oprávnění. Škola pro řidiče motorových vozidel měla být zřízena v každém krajském městě a v prípadě potřeby i v jiných větších městech kraje.

35 ŠTEMBERK, Branný sbor československých motoristů 1938-1939, s. 239.

36 Národní shromáždění RČS 1948-1954, Tisk č. 449. Důvodová zpráva k vládnímu návrhu zákona o provozu na veřejných silnicích. [online]. Dostupná na: https://www.psp.cz/eknih/1948ns/tisky/t0449_02.htm. [cit. 31. 12. 2020].

37 Tamtéž.

38 Kupon byl upraven v $\S 82$ vyhlášky č. 328/1951 Ú. 1.

39 Snížení věku pro řidiče vozidel určených k veřejné dopravě osob z 24 let na 21 let přinášelo již vládní nařízení č. 147/1944 Sb. z. a n., které však snižovalo i požadovanou praxi na dva roky. 
Doškolování řidičů bylo vnímáno jako důležitý krok ke snížení nehodovosti. Dobové statistiky uváděly, že většina dopravních nehod byla způsobena neznalostí či nedodržováním pravidel provozu na silnicích. Výcviková správa autoklubu připravila pro řidiče nedělní kursy. Ty bylo jednak možné navštěvovat dobrovolně, př́padně jejich návštěva mohla být uložena pachatelům závažných přestupků orgány SNB. Za nedělní kurs musel hř́šník na počátku 50. let zaplatit $100 \mathrm{Kč} .{ }^{40}$

Součástí nové Mezinárodní úmluvy o silničním provozu z roku 1949 bylo i nové unifikované mezinárodní dělení skupin řidičských oprávnění A - E. ${ }^{41}$ Unifikace měla vést ke sjednocení a vzájemné kompatibilitě. Tento mezinárodní závazek pronikl i do vnitrostátního práva v prováděcí vyhlášce ministerstva dopravy č. 328/1951 Ú. 1. Požadavek řidičského průkazu byl stanoven pro všechny řidiče s výjimkou řidičů vozidel, jejichž rychlost nepřesahuje $12 \mathrm{~km} / \mathrm{h}$ a motor má výkon nejvýše 6 koňských sil. Řidičská oprávnění byla nově udělována bez ohledu na druh pohonu motorových vozidel. Skupina A zahrnovala motocykly a motorové tř́íkolky. Do skupiny B byly zařazeny osobní automobily a lehké nákladní automobily (do 3,5 t). Do skupiny $\mathrm{C}$ patřily těžké nákladní automobily (přes 3,5 t), pracovní stroje a traktory s rychlostí vyšší než $30 \mathrm{~km} / \mathrm{h}$. Skupina D náležela autobusům. Držitel skupiny E mohl k vozidlům kategorie $\mathrm{B}, \mathrm{C}, \mathrm{D}$ připojit těžký přívěs. Poslední skupina T opravňovala k řízení traktorů a strojů s maximální rychlostí do $30 \mathrm{~km} / \mathrm{h}$ (§ 73). Podrobnosti k zastupitelnosti jednotlivých skupin upravoval § 76 vyhlášky. Též v otázce věku řidičů nedocházelo $\mathrm{k}$ větším změnám, motocykly do $150 \mathrm{ccm}$ a traktory bylo možné řídit od 16 let, ostatní vozidla od 18 let, pouze u autobusů a osobních automobilů sloužících k veřejné dopravě (taxi) byl vyžadován věk 21 let (§ 76). Odborná způsobilost se prokazovala zkouškou, jejíž průběh garantoval krajský národní výbor, zkoušku z pravidel silničního provozu prováděl orgán národní bezpečnosti. S osobou ustanoveného zkušebního komisaře se nadále nepočítalo. Bez prokazování předchozí praxe bylo možné získat řidičský průkaz skupin A, B a T, u ostatních skupin byla předchozí praxe v řízení motorových vozidel vyžadována (§ 85). Řidičské oprávnění bylo udělováno na dobu deseti let, po jejím uplynutí musel řidič požádat o prodloužení. Pro prodloužení bylo vyžadováno splnění obecných podmínek (zdravotní způsobilost, spolehlivost) a nebylo vyloučeno ani možné přezkoušení. Předpis však platil jen dva roky, proto toto ustanovení nemohlo mít podstatný reálný dopad. Ridičské adepty mohli připravovat pouze učitelé, kteří $\mathrm{k}$ tomu získali od krajského národního výboru oprávnění ( $\$ 94)$.

Výcvik řidičů probíhal na půdě autoklubu (do roku 1952 Autoklubu RČS, v roce 1952 Dobrovolného svazu lidového motorismu, od roku 1953 v rámci Svazu pro spolupráci $\mathrm{s}$ armádou /Svazarmu/, jako organizace československých motoristů). Výcvik měl být určen zvláště pracujícím a ze strany vedení autoklubů byl na regionální složky vyvíjen tlak na rostoucí počty vycvičených osob, který je patrný zvláště na počátku 50. let a postupně klesá, projevoval se i poklesem nároků na uchazeče o řidičské oprávnění a masovostí probíhajících kursů. ${ }^{42}$ Ceny řidičského výcviku v rámci jednotlivých skupin uvádí

40 SNA, fond PV-BO, kart. 472, sg. BC, Spis 258/33-BC-49.

41 NA, fond ÚPV, kart. 828, i. č. 3221, sig. 809/9, Mezinárodní úmluva o silničním provozu.

42 SOkA Olomouc, fond Svazarm - okresní automotoklub Šternberk, kart. 1, Výcvik členů DSLM v řízení motorových vozidel v základních organizacích, prozatímní pokyny, 22. 7. 1952. 
následující tabulka. Je zřejmé, že členství v autoklubu vedlo k nižším cenám. Vidina levnějšího řidičského výcviku byla motivem vstupu do svazarmovských automotoklubů i v následujících letech.

Ceny kursů uchazečů o řidičský průkaz v roce 1952 (částky uvedeny v Kčs)

\begin{tabular}{|l|c|c|c|c|c|c|c|}
\hline Skupina ŘP & A & B & $\mathbf{C}$ & $\mathbf{T}$ & $\mathbf{A}+\mathbf{B}$ & $\mathbf{A}+\mathbf{C}$ & $\mathbf{A}+\mathbf{T}$ \\
\hline Běžný zájemce & 650 & 1800 & 2150 & 1050 & 2200 & 2550 & 1500 \\
\hline Organizovaný člen & 650 & 1600 & 1850 & 850 & 1950 & 2250 & 1200 \\
\hline
\end{tabular}

Pramen: SOkA Olomouc, fond Svazarm - okresní automotoklub Šternberk, kart. 1, Výcvik členů DSLM v řízení motorových vozidel v základních organizacích, prozatímní pokyny, 22. 7. 1952.

Po velmi krátké době již v roce 1953 byla přijata nová pravidla provozu na československých silnicích. Vládní nařízení č. 54/1953 Sb. o provozu na silnicích rušilo zákon č. 56/1950 Sb. Organizaci výcviku řidičů řídilo ministerstvo dopravy. Nařízení bylo základem pro vznik dopravních inspektorátů, kterým bylo uloženo dohlížet na provádění výcviku a školení řidičů (§ 3). Výcvik mohly provádět Svazarm, závody, orgány státní správy a školy pro své žáky, pokud byl výcvik obsažen v osnovách, a ,ve výjimečných př́ípadech též odborně způsobilí řidiči“ ( $(5)$ ). To stanovila prováděcí vyhláška ministerstva dopravy č. 197/1953 Ú. 1. (§ 60 a 61). Výcvik řidičů mohli vykonávat pouze učitelé, kteří vyhovovali podmínkám stanoveným vyhláškou č. 196/1953 Ú. 1., učiliště též musela disponovat pomůckami $\mathrm{k}$ výcviku v rozsahu předepsaném osnovou řidičských kursů. Aktualizovaná učební osnova výcviku byla vydána v částce 157 Ú. 1. z roku 1953.

Prováděcí vyhláškou č. 196/1953 Ú. 1. byl dočasně opuštěn mezinárodní systém písmenného značení skupin řidičských oprávnění. Mohlo to souviset i s jistým uzavřením Československa, kdy mezinárodně kompatibilní systém nebyl zcela nezbytný. Nově byli řidiči rozděleni na dvě skupiny - amatérů a profesionálů. S ohledem na skutečnost, že občan nemohl pro svou potřebu vlastnit nákladní automobil a ani autobus, umožňoval řidičský průkaz řidičů amatérů jen řízení osobních automobilů a motocyklů. Průkazy řidičů z povolání byly rozděleny do tří tř́íd (§ 58). Nejvyšším stupněm byl průkaz řidiče I. trrídy, který opravňoval k řízení všech motorových vozidel (s výjimkou trolejbusů), řidič byl současně automechanikem. Řidičský průkaz II. stupně se od předchozího odlišoval jen v technických znalostech, kdy řidič nebyl automechanikem, ale pouze seřizovačem. Řidičský průkaz III. tř́ídy neumožňoval řízení autobusů a vozidel s právem přednosti v jízdě.

V návaznosti na tuto změnu byla od 1. září 1954 spuštěna velká výměna řidičských oprávnění, která měla vést ke sjednocení typů používaných řidičských průkazů a zpřesnit evidenci. V oběhu byly stále řidičské průkazy vydávané podle zákona č. 81/1935 Sb. z. a n., nařízení č. 243/1939 Sb. z. a n., či vyhlášky č. 328/1951 Ú. 1. Nemělo se však jednat jen o formální výměnu. S poukazem na potřebu zvýšit kvalifikaci řidičů a bezpečnost na silnicích se každý držitel musel před vydáním nového řidičského průkazu podrobit zkoušce ze znalostí předpisů, pokud nemohl prokázat, že v průběhu posledního roku řídil motorová 
vozidla, na která měl oprávnění, ${ }^{43}$ tak i přezkoušení z praktické jízdy. Lhůta byla stanovena do 31. prosince 1956, kdy platnost starých řidičských průkazů zanikala. ${ }^{44}$

Podle směrnic ministerstva dopravy bylo v roce 1954 zahájeno dopravní, hospodářské a technické školení řidičů z povolání. Účelem bylo zvýšení odborné úrovně řidičů, snížení nehodovosti a zlepšení technického stavu vozidel. Školení bylo rozděleno do 40 hodin ročně, zpravidla bylo rozdělené na čtyři hodiny měsíčně. ${ }^{45}$ Proškolování mohly provádět př́mo závody, což bylo obvyklé u podniků zaměřených na dopravu, nebo jím podniky mohly pověřit samozřejmě za úplatu Svazarm. Došlo tak k zavedení pravidelného proškolování řidičů z povolání, které trvá dodnes.

Podle plánů Svazarmu měly být kurzy organizovány ve všech okresních městech a také v rámci velkých závodů v krajích v tzv. závodních školách práce. Svazarm organizoval dva typy výcviku řidičů. Jeden byl určen pro budoucí brance a předcházel jejich nástupu na vojenskou službu. Tento výcvik měl z pohledu vedení Svazarmu prioritní význam. Druhým typem byly kursy pro civilní veřejnost. Ty byly z ekonomického hlediska zajímavější. $\mathrm{V}$ 50. letech se zájemce $\mathrm{z}$ řad civilní veřejnosti dařilo uspokojovat jen s velkým nasazením. Na konci roku 1957 čekalo jen v Ústeckém kraji na zařazení do výcviku 4218 žadatelů. Právě konec 50. let byl ve znamení zlepšování vybavení autoučilišt', tím se dařilo čekání zkracovat. Ke konci prosince 1959 již bylo nevyřízených jen 1756 žadatelů a čekání na zařazení do kursu se podařilo zkrátit na průměrně čtyři měsíce od podání př̌ihlášky. ${ }^{46}$ Výcvik v rámci tzv. závodních škol práce byl často kritizován, bylo poukazováno na jeho nízkou kvalitu a úroveň. Postupně bylo od této masové formy upouštěno.

Ve schválených jednotných učebních plánech bylo na přípravu motocyklisty počítáno se 79 hodinami ( $\mathrm{z}$ toho 33 hodin předpisy a 9 hodin jízdy) výcviku, pro řidiče osobního automobilu se 103 hodinami (z toho 33 hodin předpisy a 14 hodin jízdy) výcviku a pro řidiče III. třídy se 158 hodinami (z toho 39 hodin předpisy a 23 hodin jízdy). Zbytek byl počítán na techniku motorových vozidel a údržbu. Pro řidiče II. a I. třídy již školení v předpisech neprobíhalo vůbec, nebot' již předem museli být držiteli řidičského průkazu III. trrídy a většina kursu byla jen o technické stránce a údržbě. ${ }^{47}$

V závěru 50. let byly v autoučilištích Svazarmu za výcvik účtovány následující poplatky: motocykl 298 Kčs, osobní automobil 626 Kčs, traktor 595 Kčs a u řidičů III. třídy (nákladní automobily) 1300 Kčs. ${ }^{48}$ Řidičské oprávnění pro řidiče I. a II. třídy bylo získáváno prostřednictvím závodů.

Vyhláška ministerstva vnitra č. 145/1956 Ú. 1. o provozu na silnicích nepřinášela v oblasti výcviku řidičů zásadní změny a totéž lze uvést i o vyhlášce ministerstva dopravy č. 145/1958 Ú. 1. Na řidiče malých motocyklů do 50 ccm dolehla vyhláška č. 141/1960 Sb., která přinesla povinnost získat řidičský průkaz, nebot’ „odborná způsobilost k řízení

43 Směrnice o dopravním, hospodářském a technickém školení řidičů z povolání uveřejněné v př́lloze II. úředního sdělení ministerstva dopravy v částce 11 Ú. 1. z roku 1954.

44 Jak bude provedena výměna řidičských průkazů. Práce, 10. 4. 1954, s. 7.

45 JEŘÁBEK, V. a kol. Kapesni príručka pro řidiče z povolání. Praha: Dopravní nakladatelství, 1960, s. $166-167$.

46 SOkA Most, fond Svazarm - Krajská organizace Ústí nad Labem (dále jen Svazarm Ústí n. L.), kart. 10, Zpráva o činnosti Krajské správy autoučilišt' Ústí n. L., 25. 2. 1959.

47 JĚ́ÁBEK, $c$. d., s. 164.

48 JEŘÁBEK, c. d., s. 166. 
malého motocyklu se prokazuje zvláštním oprávněním“ ( $\$ 55)$. Pro dosavadní vlastníky byla tato povinnost stanovena od 1. ledna 1962 (§ 56). Malé motocykly byly též podřízeny pravidlům provozu platným pro motocykly s výjimkou nutnosti používat ochrannou přilbu. Před autoučilišti Svazarmu tak vyvstával úkol řidiče malých motocyklů proškolit a připravit na zkoušky.

Vyhláška ministra vnitra č. 87/1964 Sb. o řidičských průkazech znamenala návrat k rozdělení skupin řidičských oprávnění podle jednotlivých písmen. Ve své podstatě se jednalo o návrat $\mathrm{k}$ situaci z počátku 50. let. Novinkou bylo zavedení skupiny $\mathrm{M}$, tedy malých motocyklů do $50 \mathrm{ccm}$. K ř́zení skupiny $\mathrm{M}$ opravňovalo řidičské oprávnění jakékoli jiné skupiny. Pro řízení vozidel skupiny M dostačoval věk 15 let, o rok byl zvýšen věk řidičů motocyklů a traktorů (na 17 let), jinak platil věk 18 let, a pro řidiče autobusů 21 let. Oprávnění skupiny M a T neplatila při jízdě do zahraničí. Každý uchazeč se musel podrobit ještě před zahájením výcviku lékařské prohlídce, teprve s jejím kladným výsledkem mohl být výcvik zahájen. ${ }^{49}$ Beze změn zůstal i pohled na spolehlivost řidičů. Nespolehlivý uchazeč nemohl být do výcviku zařazen. Spolehlivý nebyl ten (§ 7), kdo se dopustil přestupku, provinění či trestného činu, ze kterého vyplývalo, že nemá dostatek kázně pro řízení motorových vozidel, požívá často a nadměrně alkoholické nápoje či omamné prostředky, a osoba, které bylo řízení motorových vozidel soudem zakázáno. Pohled na spolehlivost se tak v zásadě od roku 1910 nezměnil.

Každý žadatel o řidičské oprávnění musel projít výcvikem. Stále však existovala výjimka umožňující žadatelům o oprávnění skupiny A, B a M podstoupit individuální výcvik (povoloval okresní dopravní inspektorát) pod vedením cvičitele, který měl alespoň dvouletou řidičskou praxi pro příslušnou skupinu. Po ukončení výcviku následovala zkouška, kde bylo zjišt'ováno, zda si adept osvojil učební látku a je schopen v provozu bezpečně vozidlo ovládat. V průběhu zkoušky se zjišt'ovala znalost pravidel silničního provozu, nauka o vozidlech a praktická jízda. Součástí zkoušky mohla být i výměna pneumatiky, žárovky či popis průběhu výměny oleje. V případě, že žadatel neuspěl v některé dílčí části, musel opakovat celou zkoušku. Zkouška mohla být opakována pouze dvakrát, v př́padě neúspěchu u druhé opravy musel následovat nový výcvik. Zkoušky prováděl okresní dopravní inspektorát (§ 9). Zvláštní pravidla platila pro řidiče vojenských vozidel (§ 19). $\mathrm{V}$ př́ípadě rozšíření na druh vozidel, ke kterým řidič oprávnění neměl, musel se podrobit doplňujícímu výcviku a zkoušce. Poněkud zvláštní postavení měla skupina E (těžké přívěsy), odvíjela se od dosavadních skupin B, C a D. Žadatel o rozšíření na skupinu E se nepodroboval výcviku a ani zkoušce, pouze musel prokázat, že vozidla, ke kterým chce těžký přívěs připojovat, aktivně řídí (§ 11). Komisaři z dopravního inspektorátu prováděli vždy zkoušky z pravidel silničního provozu, dále též praktické jízdy, jen u skupin A a T zkoušeli jízdy přímo učitelé autoškol.

Součástí řidičského průkazu stále zůstávala vložka evidující nejvážnější přestupky. Přímo ve vyhlášce byla uvedena možnost přezkoušení odborné způsobilosti v případě, že pro to existují vážné důvody. Tyto důvody závisely na posouzení dopravního inspektorátu. Vyhláška již nepočítala s časovým omezením platnosti řidičského oprávnění a jeho možným prodlužováním. Vycházela z konceptu jednoho výcviku a jedné zkoušky na počátku

49 Směrnice pro lékařské prohlídky řidičů vydalo ministerstvo zdravotnictví pod č. 32/1963 Sb. směrnic pro národní výbory. 
řidičské kariéry a její neomezené časové platnosti, pokud nedojde k nějaké výjimečné situaci.

V roce 1970 (vyhláška č. 95/1970 Sb.) byla zavedena povinnost pravidelných kontrol zdravotního stavu pro všechny držitele řidičského průkazu. Dosud se týkala jen řidičů z povolání (zvláště řidičů autobusů). Prohlídka byla zavedena v závislosti na věku řidiče, první prohlídku musel absolvovat po dosažení věku 60 let, znovu poté po dosažení 65 a 68 let, následně pak každé dva roky. Potvrzení od lékaře musel řidič předložit na příslušný dopravní inspektorát. Řidiči, kterým již bylo v době vydání vyhlášky 60 let a více, museli potvrzení předložit do šesti měsíců, tedy do 28. dubna 1971. Před rokem 1970 mohlo být řidiči nařízeno přezkoumání zdravotní způsobilosti, pouze pokud byla o jeho zdravotním stavu důvodná pochybnost. Nedodržení povinnosti podrobit se lékařské prohlídce mohlo mít i nepř́ijemné důsledky v trestní rovině. Pokud řidič senior zavinil dopravní nehodu v důsledku nějaké zdravotní komplikace a neměl potvrzení o své zdravotní způsobilosti, mohlo být jeho jednání posouzeno jako porušení důležité povinnosti uložené podle zákona a tím i naplnění znaků kvalifikované skutkové podstaty (srov. Rozhodnutí Nejvyššího soudu SSR 8 Tz 72/85 z 25. ř́ijna 1985).

Podrobnější pravidla výcviku přinášela vyhláška ministerstva dopravy č. 53/1965 Sb. o výcviku a dalším zvyšování odbornosti řidičů motorových vozidel. Okruh oprávněných organizací k provádění výcviku se neměnil (Svazarm, školy, státní organizace). Jednoznačně vedl Svazarm, jehož autoškolami prošlo více než 80 \% vycvičených řidičů. ${ }^{50}$ Tyto organizace odpovídaly za úroveň výcviku. Dohled nad výchovou řidičů přecházel z krajských na okresní národní výbory. Tato změna pravděpodobně souvisela s reformou správní organizace v roce 1960 a pokračujícím rozvojem motorismu. Základní pilír výcviku řidičů představovaly autoškoly Svazarmu, který pro občany pořádal řidičské kursy. Posílen byl i výcvik řidičů na školách, kde mohla být výuka řidičů i nepovinným předmětem. Státní organizace mohly provádět výcvik jen pro své zaměstnance, pokud to bylo pro jejich činnost nezbytné ( $§ 1)$.

Na rozdíl od drrívější doby, kdy se jednalo převážně o střední školy dopravního zaměření, se jednalo i o školy, jejichž výuka nebyla s dopravou spojena (např. i gymnasia). Studenti si volitelný předmět zapisovali podle svého zájmu, ale obvyklé bylo i omezení možnosti jeho absolvování předchozími studijními výsledky. Výcvik (na motocykly a osobní vozy) v rámci školní výuky byl realizován za zvýhodněných podmínek se státním př́ispěvkem (v polovině 70. let byl výcvik na osobní automobil za 500 Kčs). Volitelný předmět Řízení motorového vozidla mohl být v rámci střední školy zařazen do třetího ročníku, případně do druhého pololetí tř̌etího a prvního pololetí čtvrtého ročníku. Student, který si předmět zapsal, byl z tohoto volitelného předmětu i klasifikován. ${ }^{51} \mathrm{U}$ škol dopravního zaměření bylo běžné, že část výcviku probíhala pedagogy dané školy, nicméně u ostatních škol bylo obvyklé, že předmět byl vyučován ve spolupráci se Svazarmem, který učitele pro teoretickou i praktickou výuku zajistil a škola poskytla pro výuku prostory. ${ }^{52}$ Na základních školách mohly být zakládány motoristické kroužky, které žákům devátých tříd umožnily složení řidičského průkazu na malý motocykl. ${ }^{53}$

\footnotetext{
50 HOSKOVEC, J. a kol. Výcvik řidičů a psychologie. Praha: Nakladatelství dopravy a spojů, 1972, s. 10.

51 DOLEŽAL, S. Dopravní výchova mládeže. Odborná výchova, 1979-1980, roč. 30, č. 2, s. 60.

52 SOkA Písek, fond Autoškola Svazarmu Písek, Kronika.

53 SOkA Most, fond Svazarm Ústí n. L., kart. 15, Zpráva o činnosti na úseku motorismu, 18. 5. 1965.
} 
Cílem výcviku bylo získat teoretické i praktické dopravně-provozní a technické znalosti potřebné $\mathrm{k}$ dokonalému ovládání vozidla a jeho hospodárnému provozu (§3). Výuka byla prováděna zpravidla $\mathrm{v}$ hromadných kursech s maximálním počtem posluchačů $35 \mathrm{Na}$ počátku kursu si posluchači museli osvojit základní pravidla provozu na silnicích, seznámit se s teorií rízení a technikou jízdy. Jedna lekce rrízení trvala 25 minut a žák mohl zpravidla absolvovat dvě lekce za den. Během jedné lekce měl řidič ujet cca $10 \mathrm{~km}$ (u traktoru $5 \mathrm{~km}$ ). Výcvik adeptů mohli provádět jen učitelé, kterým bylo krajským dopravním inspektorátem vydáno osvědčení pro učitele. Osvědčení bylo vydáváno po složení zkoušky, která prokazovala nejen odborné vzdělání, svědomitost, ale i pedagogické dovednosti. Vydávalo se na dobu pěti let, kdy následovalo přezkoušení učitele. Pro učitele autoškol byla předepsána kvalifikace alespoň nižší průmyslová škola dopravního směru a rok pedagogického studia. Učitelé autoškol podstupovali odbornou a pedagogickou př́pravu, která probíhala ve škole Ústředního výboru Svazarmu v Krupce. Realita však byla poněkud vzdálena. V roce 1970 požadovanou kvalifikaci splňovalo jen $65 \%$ stálých učitelů, kteří však tvořili jen menšinu (cca 40 \%). Ostatní pedagogové byli externisty, mezi nimiž byl podíl nedostatečně kvalifikovaných též značný. Ukazovalo se tak, že „,by to s odbornou úrovní mohlo být lepšíi. 54 Učitelé výcviku řidičů se povinně sdružovali v motoristických katedrách Svazarmu (§ 4). Vedoucí výcvikového zařízení (autoškoly) odpovídal za to, že učitel bude učit jen předměty, k jejichž výuce byl oprávněn. ${ }^{55}$ Povolání řidiče v autoškole bylo dlouhodobě výsadou mužů. Teprve v 80. letech začaly na tato místa pronikat ženy. Př́íkladem může být situace v Západočeském kraji, kde v roce 1982 byly ze 112 učitelů jen čtyři ženy, do roku 1987 se počet žen zdvojnásobil (celkově osm ze 125 učitelů). ${ }^{56}$ Nová učební osnova pro autoškoly platná od 1. července 1965 rozšírila hodiny praktického výcviku na úkor teorie o stavbě motorového vozidla, která měla pro běžného řidiče menší význam než správné ovládání vozidla v provozu.

Ceny výcviku sice byly regulovány a nastavovány centrálně, nicméně je možné sledovat jejich postupný růst. Na počátku 70. let platily v autoškolách následující ceny: malý motocykl 104 Kčs, motocykl 327 Kčs, osobní automobil 922 Kčs, nákladní automobil 2143 Kčs, pro všechny druhy motorových vozidel 2440 Kčs. ${ }^{57}$ Výcvik se měl zaměřovat na kvalitní přípravu, zvláštní důraz byl kladen na správné a bezpečné ovládání vozidla v provozu. Hlavním úkolem bylo naučit budoucí řidiče bezpečně jezdit. Ke zlepšení výcviku řidičů nabádala i politická doporučení a směrnice. V důsledku růstu nehodovosti se tímto tématem zabýval i Ústřední výbor KSČ, který zdůraznil, že hlavní pilír prevence nehodovosti je kvalitní prŕprava v autoškolách. Právě na tu se měla celá pozornost zaměřit. Zkoušky adeptů měly být př́ísné. Výcvik i zkoušky cílily na eliminaci osob, které neměly $\mathrm{k}$ ř́zení předpoklady, i když obecné podmínky splňovaly. ${ }^{58}$

Cvičná vozidla musela být v socialistickém vlastnictví a s výjimkou malých motocyklů a autobusů mít dvojí řízení. V běžném provozu musela být označena nápisem „Cvičná jízda“. K výcviku měla být používána vozidla, která byla běžná v provozu. Výcvik

\footnotetext{
54 Jak školíme nové řidiče? Svět motorů, 1971, roč. 25, č. 3, s. 3.

55 Státní oblastní archiv Plzeň (dále jen SOA Plzeň), f. Svazarm - Krajský inspektorát autoškol Plzeň, kart. 1, i. č. 1, Vedoucím výcvikových zařizení Západočeského kraje, 5. 6. 1975.

56 Tamtéž, kart. 3, i. č. 4, Sumář k hlášení počtu pracovníků.

57 Chci vědět. Svět motorů, 1971, roč. 25, č. 3, s. 5.

58 SOkA Most, fond Svazarm Ústí n. L., kart. 11, Zpráva o činnosti, 18. 1. 1961.
} 
na zastaralých či neobvyklých typech dovolen nebyl. V 50. letech se autoškoly potýkaly s akutním nedostatkem výcvikových vozidel, jejich zastaralostí a nedobrým technickým stavem. Ve druhé polovině 50. let mívala autoučiliště k výcviku průměrně dva osobní vozy, tři motocykly a tři nákladní auta. Při poruše jednoho osobního auta se výcvik dostával do komplikované situace. ${ }^{59}$ Postupné zlepšování bylo patrné od přelomu 50. a 60. let. Náznak zlepšování byl spojen s nahrazováním starých aut předválečné a těsně poválečné provenience (např. Tatry 57). Teprve v průběhu 60. let se dařilo situaci stabilizovat. Výcvik probíhal převážně na vozidlech domácí výroby, případně ze zemí socialistického bloku (např. Moskvič). V 70. letech se podíl vozidel domácí výroby zvyšoval, a zvláště mezi osobními automobily byly zastoupeny vozy značky Škoda. Na počátku 70. let disponovaly svazarmovské autoškoly v českých zemích 2400 cvičnými vozy. Roční nákup nových vozů se pohyboval mezi 400 až 500 kusy. ${ }^{60}$ To napomáhalo i snižování stáří výcvikových vozidel, jež se u osobních aut pohybovalo do pěti let, obdobné to bylo i u motocyklů. V 70. letech probíhal výcvik většinou na vozidle Škoda 100 L a v letech 80 . na vozech Škoda 105 L. Vyššího stáří byly jen traktory a nákladní automobily, kde se pohybovalo okolo 10 let. ${ }^{61}$

Nová a podrobnější pravidla získalo i zvyšování odborných znalostí řidičů. To probíhalo v rovině zácviku řidiče, pravidelného povinného poučování řidičů z povolání a v péči o další odborný růst ostatních řidičů. Zácvik se týkal řidičů z povolání před svěřením nového typu vozidla. Povinné poučování řidičů z povolání mohly provádět organizace pro své zaměstnance, případně touto činností pověřit Svazarm, což se zvláště u menších podniků, kde doprava nebyla hlavním předmětem činnosti, obvykle dělo. Oproti dosavadnímu stavu se nezměnil rozsah, který zůstával 40 hodin ročně (obvykle čtyři hodiny měsíčně). V rámci přednášek se probírala témata z oblasti změn v pravidlech silničního provozu, techniky (hospodárnost jízdy, údržba apod.), ale i práva (odpovědnost řidiče), bezpečnosti a ochrany zdraví při práci, provozu podniku či zdravotnictví. Přezkušování znalostí se týkalo jen řidičů v hromadné dopravě osob či v přepravě nebezpečných nákladů, a to nejméně ve dvouletých intervalech (§ 17). O odborný růst řidičů amatérů měl pečovat Svazarm, žádná bližší pravidla však stanovena nebyla. V této oblasti se Svazarm zaměřoval na nabídku kondičních jízd, organizaci osvětových kursů pro řidiče o prríčinách nehodovosti, novinky v pravidlech silničního provozu, ale podílel se i na bezpečnostních soutěžích (např. Jezdím bez nehod). V případě kondičních jízd však vyvstávala řada právních nejasností, daných stručnou formulací poučování řidičů amatérů. S ohledem na pravidla fungování Svazarmu se ukazovalo, že za úplatu mohla být tato činnost prováděna jen pro členy Svazarmu. Nejasná zůstávala i odpovědnost řidiče, který již nebyl uchazečem o řidičské oprávnění, a odpovědnost Svazarmu. ${ }^{62}$

Nové úpravy se výcvik řidičů dočkal vyhláškou federálního ministra dopravy č. 94/1972 Sb. V rámci rozdělení kompetencí mezi federaci a republiky byla oblast výcviku řidičů začleněna do kompetence federace a měla být jednotná na celém území státu. Tomu samozřejmě nebránilo, že Svazarm se v rámci federace rozdělil. Výcvik řidičů se stal úkolem

59 Tamtéž, kart. 10, Zpráva o činnosti Krajské správy autoučilišt' od 24. 12. 1957 do 23. 5. 1958.

60 Svět motorů se ptá, František Hynek ředitel Autoškol ÚV Svazarmu ČSR odpovídá. Svět motorů, 1971, roč. 25 , č. 39 , s. 3 .

61 SOA Plzeň, fond Svazarm - Krajský inspektorát autoškol Plzeň, kart. 4, i. č. 5, Zpráva č. 3/1986.

62 Podrobněji: SVOBODA, M. K některým právním otázkám forem zvyšování odborné způsobilosti řidičů silničních motorových vozidel. Socialistická zákonnost, 1977, roč. 25, č. 6, s. 350-356. 
samostatného oddělení autoškol ústředního výboru Svazarmu ČSR / SSR. S výjimkou této spíše organizační změny nedošlo v organizacích provádějících výcvik ke změnám. Výcvik jízd již neprobíhal ve 25minutových lekcích, ale v 50minutových hodinách, kdy žák měl absolvovat zpravidla hodinu (maximálně dvě hodiny) denně. Tomu se úměrně prodloužila průměrná vzdálenost, kterou měl adept během hodiny ujet, na $20 \mathrm{~km}$ (u traktoru $10 \mathrm{~km}$ ).

Od 70. let můžeme sledovat nástup nových trendů do prrípravy řidičů i nových pomůcek. Dosavadní pomůcky, spočívající v modelech částí vozu, nákresech, odborných knihách či výukových filmech, byly rozšiřovány o trenažéry, na kterých stále častěji probíhala první jízda, aby si adepti osvojili základní postupy mimo ostrý provoz, či autodromy (autocvičiště), kde mohli uchazeči cvičit jízdy bez osobní přítomnosti instruktora ve voze, pouze pod jeho dohledem. S nástupem nových pomůcek vyvstávala i otázka vhodných učeben. Prostá třída již nevyhovovala a bylo nutné přistupovat k výstavbě nových objektů, které by novým trendům odpovídaly (v roce 1971 bylo v českých zemích 12 trenažérových učeben). Dílčím způsobem byly zpřísněny nároky na učitele, kdy byl vyžadován minimální věk 23 let a pro učitele praktických jízd 25 let. Osvědčení učitele bylo nadále vydáváno a prodlužováno na pět let ( $(4)$. Viditelnou změnou prošlo i označení cvičných vozidel. Vozidla s výjimkou motocyklů musela mít na střeše umístěnu tabulku ve tvaru obdélníku s nápisem „Autoškola“ (autobusy a nákladní vozy musely mít tento nápis i na zádi). Označení „Cvičná jízda“ zůstalo jen motocyklům, kde muselo být na prsou žadatele a zádech učitele. ${ }^{63}$ Požadavek, aby cvičné vozidlo bylo v náležitém technickém stavu, nebyl nový, nicméně novinkou byla povinnost vozidlo každých šest měsíců přistavit k technické kontrole. Toto opatření mělo vést ke zlepšení technického stavu parku vozidel autoškol.

Z oblasti zvyšování odborné způsobilosti řidičů byl vypuštěn zácvik, což nebylo překvapivé, nebot' se týkal více vnitřního fungování podniku a převažovala technická stránka ovládání vozu. Změn se dostalo i povinnému poučování řidičů z povolání. Byl sice zkrácen jeho rozsah na 32 hodin ročně a nebylo nadále vyžadováno rovnoměrné rozvrhování do jednotlivých měsíců, ale současně na závěr vždy následovalo přezkoušení ze znalostí pravidel silničního provozu. V prŕípadě neúspěchu měl řidič z povolání jeden opravný termín. ${ }^{64}$ Neúspěch při přezkoušení řidiče z povolání mohl mít dopad i na běžný život, nebot' neúspěch musel podnik hlásit na dopravní inspektorát. Na konci tak mohla být ztráta řidičského oprávnění.

Pověření Svazarmu výcvikem řidičů přinášelo nemalý finanční profit, autoškoly patřily tradičně k ziskovým zařízením. Svazarm, který se zaměřoval na podporu brannosti, vycházel z premisy, že „motoristický výcvik je jedním ze základních druhů branné přípravy ve svazarmovské činnosti“. ${ }^{65}$ Stoupající zájem o výcvik řidičů i podpora tomuto výcviku, která ve druhé polovině 50. let přicházela, se promítly i v organizační struktuře. Od ledna 1957 byla vytvořena nová organizační struktura vycházející z krajského uspořádání. Byly vytvořeny krajské správy autoučilišst, které převzaly do své správy autoškoly a údržbárny v krajích. Propojení s údržbárnami mělo skýtat zázemí i pro teoretickou výchovu žáků. ${ }^{66}$ V souvislosti se správními změnami bylo Ústředním výborem Svazarmu dne 21. dubna

63 Podle vyhlášky z roku 1965 cvičné motocykly nemusely být označeny.

64 Opravný termín byl zrušen novelou provedenou vyhláškou č. 20/1982 Sb.

65 SOkA Most, f. Svazarm Ústí n. L, kart. 10, Zpráva o činnosti Krajského automotoklubu Ústí n. L., 6. 7. 1958.

66 Tamtéž, kart. 9, Zpráva o činnosti Krajské zprávy autoučilišt’ Svazarmu Ústí n. L. 
1961 rozhodnuto převést autoškoly z působnosti krajských do působnosti okresních výborů Svazarmu. Tímto směrem se posouvaly i kompetence dopravních inspektorátů. ${ }^{67} \mathrm{Na}$ krajské úrovni byly vytvořeny inspektoráty autoškol, které kontrolovaly jejich činnost jak v otázce výcviku, tak i ekonomického fungování. Federalizace státu dopadla i na Svazarm. Oblast autoškol byla přičleněna republikovým ústředním výborům. Základním požadavkem bylo zajistit výcvik podle stejných pravidel na celém území státu.

V návaznosti na vyhlášku č. 94/1972 Sb., byly výnosem ze dne 22. listopadu 1973 vydány učební osnovy výcviku řidičů silničních motorových vozidel. Dílčí liberalizaci přinesla novela č. 107/1979 Sb., která zkracovala hodinu jízdy na 45 minut a snižovala minimální věk učitele v autoškole na 21 let.

Pokud na přelomu 50. a 60. let dostačovalo organizování výcviku řidičů na úrovni okresních měst, tak v letech 70. se již uplatňovala zásada „,ne občané za námi, ale my musíme jít za občany“. ${ }^{6}$ Organizování kursů se přesouvalo i do menších měst, ,zkrátka všude tam, kde se najde dost zájemcư“. ${ }^{69} \mathrm{~V}$ rozvinuté socialistické společnosti měla být „komplexní řidičská příprava poskytována jako součást všeobecného vzdělání všem občanům, kteří mají pro řízení silničních motorových vozidel fyziologické a psychologické předpoklady“ ${ }^{70} \mathrm{Na}$ rozdíl od běžného vzdělání však neměla být poskytována bezplatně, naopak je možné říci, že cena výcvikových kursů setrvale stoupala a na konci 70. let výcvik řidiče osobního automobilu vyšel na několik tisíc korun.

Pokud bylo na přelomu 50. a 60. let vnímáno čekání na zařazení do výcvikového kursu v délce čtyř měsíců jako přijatelné, tak o deset let později to neplatilo. Ačkoli ročně stoupl počet zájemců cca o $5 \%$, čekání na zařazení do kursu se zkracovalo. Autoškoly měly podle usnesení Ústředního výboru Svazarmu ČSR udělat taková opatření, aby mezi podáním přihlášky a zahájením kursu neuplynuly více než tři měsíce. Délka vlastního řidičského výcviku se odvíjela od skupiny. Nejkratší, většinou měsíční, byly kursy pro získání skupiny M. Výcvik řidičů skupiny B trval většinou dva měsíce, bylo však možné najít i kurs, který trval necelý měsíc. Nejdéle trval výcvik skupiny $\mathrm{C} v$ průměru necelé tři měsíce. V případě kombinace skupin se výcvik samozrejmě prodlužoval. ${ }^{71}$

Sedmdesátá léta přinesla i rozvoj spolupráce na půdě Rady vzájemné hospodářské pomoci (RVHP). Kooperace se měla ubírat směrem ke sjednocení pravidel př́pravy řidičů ve všech členských státech podle jednotné metodiky. ${ }^{72}$ Jednalo se však spíše o plány a představy, než skutečně realizované kroky. Bezpochyby zajímavou je i skutečnost, že součástí hospodářského pětiletého plánu se stávaly i počty nově vyškolených řidičů. V rámci páté pětiletky (první polovina 70. let) měly české a moravské autoškoly vycvičit milion nových řidičů. Tento plán se podařilo splnit již 17. listopadu $1975 .^{73}$

Vyhláška federálního ministerstva vnitra č. 174/1980 Sb. o provádění zkoušek z odborné způsobilosti žadatelů o řidičská oprávnění podrobněji upravovala obsah a průběh zkoušek.

67 Tamtéž, kart. 11, Směrnice č. j. 535-2/61.

68 SOkA Písek, f. Autoškola Svazarmu Písek, Kronika.

69 Tamtéž.

70 Tamtéž.

71 SOA Plzeň, f. Svazarm - Krajský inspektorát autoškol Plzeň, kart. 4, i. č. 5, Zpráva č. 3/1986.

72 SOkA Písek, f. Autoškola Svazarmu Písek, Kronika.

73 SOA Plzeň, f. Svazarm - Krajský inspektorát autoškol Plzeň, kart. 1, i. č. 1, Zápis z porady vedoucích Autoškol konané 1. 12. 1975. 
Zkoušky nadále prováděli zkušební komisaři dopravních inspektorátů. Bez výjimky to platilo $\mathrm{v}$ případě zkoušek z teorie (pravidel provozu). V př́padě praktické části zkoušky (jízd) či nauky o motorových vozidlech a jejich údržbě mohli být pověřeni prováděním zkoušek i učitelé autoškol. Běžně tak učitelé autoškol zkoušeli jízdy u motocyklů (skupiny A, M). Žadatel mohl zkoušku opakovat pouze dvakrát, po neúspěchu druhé opravy se musel znovu podrobit celému výcviku. Zkouška z předpisů o silničním provozu se prováděla testy, na jejichž napsání bylo vymezeno 20 minut. Maximálně bylo možné dosáhnout 55 bodů, pro jednotlivé skupiny řidičských oprávnění byla stanovena minimální hranice v rozmezí 50 až 53 bodů ( $\$ 8)$. Zkouška z nauky o motorových vozidlech měla u skupin A a B prokázat základní znalost ústrojí motorového vozidla, která mají vliv na bezpečnost provozu, a schopnost provádění běžné údržby a odstraňování drobných závad. U skupin $\mathrm{C}, \mathrm{D}$ a T se mělo jednat již o pokročilou znalost konstrukce a jednotlivých součástí vozu včetně schopnosti provádět opravy. Na zkoušku v rrízení vozu bylo vyhrazeno též 20 minut. Adept měl prokázat schopnost bezpečného ovládání vozu v provozu, ale i řadu běžných úkonů (zastavení a rozjezd ve svahu, couvání apod.). Novinkou se stalo oprávnění dopravního inspektorátu uložit řidiči povinnost podrobit se přezkoušení (§ 13). Součástí rozhodnutí dopravního inspektorátu o povinnosti podrobit se přezkoušení byl rozsah tohoto přezkoušení (z pravidel, jízd). Současně mohla být uložena i povinnost absolvovat v autoškole cvičné jízdy. Přezkoušení probíhalo ve stejném rozsahu jako při zkoušce nového řidiče. Podrobnosti vyhláška neobsahovala, pro dopravní inspektoráty se tak otevíral relativně široký prostor volného uvážení.

Druhá polovina 80 . let otevírala řadu nových témat, která jsou do jisté míry nadčasová. Jedním z těchto témat bylo doškolování řidičů amatérů, které by dostalo pevnější rámec s možným výhledem na zavedení povinné účasti. Opakovaně byla diskutována náročnost výcviku. Ukazovalo se, že mladí řidiči do jednoho roku od absolvování autoškoly zavinili až o polovinu více dopravních nehod než srovnatelný vzorek zkušenějších řidičů. Po roce 1989 byly tyto úvahy opuštěny.

Pravidla pro udělování řidičských průkazů stanovená ve vyhlášce 87/1964 Sb. a pro výcvik řidičů stanovená ve vyhlášce č. 94/1972 Sb. zůstala zachována až do konce 80. let. Stejně tak monopolní postavení Svazarmu při výcviku řidičů. Důsledkem změn nastartovaných v listopadu 1989 byly i změny výcviku řidičů. V roce 1990 narůstalo napětí mezi vedením Svazarmu a jednotlivými autoškolami, které se chtěly osamostatnit. Svazarmovský rámec začali opouštět i učitelé a hledali cestu k možnostem soukromého podnikání v této oblasti. Monopol Svazarmu se tak zhroutil. Nicméně toto bezesporu zajímavé téma, které vyžadovalo nezbytně i legislativní změny, již překračuje rámec tohoto příspěvku.

\section{Závěr}

Rozvoj motorizace vyvolal na počátku 20. století v evropských státech potřebu požadovat po řidičích motorových vozidel, nejprve automobilů a výrazně později až motocyklů, znalost pravidel provozu na silnicích i bezpečného ovládání řízených vozů. Tyto schopnosti byly prokazovány zkouškou a její složení osvědčovalo přiznání řidičského oprávnění. V rámci habsburské monarchie byl tento požadavek stanoven v roce 1905. Příprava na zkoušku spočívala na adeptech a stejně tak obsah zkoušky byl stanoven velmi obecně. V meziválečném období byla s kvalitou př́pravy řidičů spojována i otázka nehodovosti, to bylo důvodem častých požadavků na její zpř́ísnění. Tyto diskuse o nalezení 
vyváženého stavu náročnosti požadavků na řidiče se vedou s větší či menší intenzitou již století. Obdobně jako v současné době, často zmiňované vyšší bezpečnostní riziko spojené s mladými řidiči bylo známo již mezi válkami. Nároky kladené na řidiče se samožrejmě ve sledované době proměňovaly. Postupně bylo ustupováno od nároků na technické znalosti z oblasti nauky o vozidlech, zvláště to bylo patrné u řidičů osobních vozů a motocyklů. Výcvik řidičů, který až do roku 1935 postrádal jasná pravidla, byl zákonem č. 81/1935 Sb. z. a n. primárně vyhrazen koncesovaným autoškolám. Úpravy se dočkal i obsah výcviku stanovením minimálních standardů. Model výcviku prostřednictvím koncesovaných autoškol zůstával zachován až do roku 1950. Nástup poúnorového režimu vnesl do této oblasti „samosprávu“ motoristických organizací. Příprava řidičů tak byla vyhrazena monopolní organizaci motoristů Svazarmu (od roku 1953). V rámci Svazarmu se vytvořil systém autoškol. Také příprava učitelů byla ve Svazarmu monopolizována. Je nutné konstatovat, že nároky na řidiče se nijak zásadně neproměňovaly. Novinkou se stalo povinné doškolování řidičů z povolání. V 80. letech byla otevřena otázka pravidelného doškolování / přezkušování všech řidičů. Nicméně události roku 1989 tyto diskuse ukončily, stejně jako monopolní postavení Svazarmu při výcviku řidičů. 